\title{
An Evaluation of Production Business Process Costs Using a Time-labour Approach
}

\author{
Viktoriya V. Grigorieva ${ }^{1}$, Anna N. Polozova ${ }^{2}$, Elena P. Borshevskay ${ }^{1}$, Nadezhda V. Kondrashova ${ }^{1} \&$ Irina V. \\ Shamrina $^{3}$ \\ ${ }^{1}$ Voronezh State University of Engineering Technologies, Russian Federation \\ ${ }^{2}$ Institute of Management, Marketing and Finance, Russian Federation \\ ${ }^{3}$ Federal State-Funded Educational Institution of Higher Professional Education "Financial University under the \\ Government of the Russian Federation", Russian Federation \\ Correspondence: Irina V. Shamrina, Federal State-Funded Educational Institution of Higher Professional \\ Education "Financial University under the Government of the Russian Federation", Russian Federation. E-mail: \\ vickierus@mail.ru; annapollo@yandex.ru; ivshamrina@yandex.ru
}

Received: November 5, 2014 Accepted: December 17, 2014 Online Published: March 20, 2015

doi:10.5539/ass.v11n8p96 URL: http://dx.doi.org/10.5539/ass.v11n8p96

\begin{abstract}
The paper explains the reasons that make it difficult to carry out an objective evaluation of ways to reduce the total costs of production. It also examines the nature of individual costs and expenses and of the production factors that are needed for the realization of business activities. It also sets out the advantages and disadvantages of methods of evaluating production factors, and of instruments for evaluating the total costs associated with them. It describes the time-labour nature of individual production costs. It also shows the different stances taken by current total cost-pricing methodologies from the standpoints of: the manufacturer's interests, utility, the impact of market competition, and the presence of monopolies in the market. The unsuitability of such an approach when evaluating the real value of the total costs of goods is shown. It is demonstrated that labour has its natural and market price, and on this basis three variants showing the correlation between cost and price of labour-power are formulated. We propose to measure total costs not in price terms, but on a time-labour principle, based on the input of working time, since labour is one of the main factors of production. An estimate of production costs based on time-labour avoids the distorting impact of value, as it reflects the original time-labour substance within total costs.
\end{abstract}

Keywords: costs of production, business process, labour, time-labour contribution

JEL: D46, M11, J01

\section{Introduction}

The entry into a market economy of processing enterprises within Russia's agro-industrial complex was accompanied by a number of inter-dependent negative phenomena, as a result of which the total costs of production of goods increased and continue to remain unjustifiably high. The overall reason for these negative consequences was the fact that the reforms that took place in Russia resulted mainly in fundamental changes in the sphere of supply, and at the same time the management of the core economic sphere - industrial and agricultural production - worsened significantly. In these conditions the fundamental principle of the market is ignored - success is determined by lower costs spent on the production of goods compared with their prices, and a reduction in both costs and price is necessary if profits are to increase. Due to the specific socio-economic conditions within the processing sector, enterprises cannot raise the prices of their products beyond a certain limit, therefore an increase in profits is achievable in reality primarily by lowering the costs incurred by the use of all forms of production resources during the entire production process, and in the management of business activities.

Preliminary research revealed the circumstances that make it difficult to carry out an objective evaluation of ways of reducing production costs in the processing sector, which result from the distorting impact of prices on the material and labour factors of production. Therefore, the authors regard as particularly important the theoretical positions of A. Marshall, J. Keynes, and J. Robinson on the economic nature and negative features of 
monopolistic prices on the factors of production; the position of E. I. Punin, who theoretically combined two approaches to the evaluation of factors of production - from the point of view of outlays on production and from the point of view of their utility, which he did not see as opposing, but as complementing each other; and the position of P. A. Ignatovsky, who sees reduction of labour costs as key to the development of production.

In today's market in Russia the exclusively high prices for energy and power resources, and industrial and transportation facilities, and exclusively low prices for raw materials and labour resources are at variance with their cost, and the indirect inclusion of these elements in an analysis of provisions for reducing production costs is a formality and insufficiently objective. We have, therefore, considered it essential to include a time element indicator when evaluating ways of reducing costs; this will eliminate this distorting impact and will measure total costs on their economic basis.

\section{Materials and Methods}

Processing plants in the Voronezh region of Russia and their raw material base were chosen as the object for research into total costs. A more comprehensive study of individual aspects of our research was carried out on the materials of enterprises whose level of costs was lower than the average. We used works of classical economics, and of modern Russian and foreign specialists in questions of labour efficiency in the production process, as our theoretical and methodological basis of research.

The methods used during research were those of a system approach to the study of economic phenomena and processes; analysis and synthesis, economic-mathematical statistics, and mathematical modelling.

\section{Discussion and Results}

The basis of cost, and separate from it in part, and which covers all production costs and expenses expressed in monetary form is, as is well known, cost-price. Cost-price determines the amount of costs and expenses that are linked to the production of goods in a particular enterprise. At an invariable price at which a competitive producer's goods are produced, his income will increase as the individual cost-price of production decreases.

A manufacturer's individual costs and expenses constitute the costs linked to payments to suppliers of production resources, that are not the property of the owners of the enterprise. The economic costs of resources, or of production factors, equal to their cost-price or value, must correspond as far as possible to their use, as income (net profit) of a particular manufacturer at a commodity's fixed price depends on the individual costs and expenses spent on its production, and which are concentrated in the cost-price.

For the realization of any business process there are a number of production factors present, considered by economic theory and management practice to be labour, land and other natural resources, and capital. An increase in profitability of the goods that are produced occurs when the gap is reduced between actual costs, accounted for in the book records, and the economic costs that are most suitable for the creation and use of production factors. This shows the importance of optimizing the structure and mass of costs and expenses during the cost-control process (Grigorieva \& Polozova, 2013).

It is of interest to study methods of evaluating the factors of production, and the instruments used to estimate costs and expenses, with the aim of optimizing these methods, and to choose the method that is most suitable for the nature of the costs.

In market economy conditions an adequate cost evaluation of the factors of production and the supply of resources must be used. For example, A. I. Arkhipov, A. I. Amosov and A. K. Bolshakov name wages, land rent and rent for other natural resources, and the rate of interest on capital and profit as the price of each of the listed factors (Amosov, Arkhipov, \& Bolshakov, 2010). The particular advantage of this method of evaluation is its uniformity and versatility. Simultaneously with this, an evaluation of exchange value (on a price basis) includes a number of significant features that do not allow a sufficiently objective determination of the level of efficiency of costs and expenses that guarantee the economic well-being of manufacturers of goods and a favourable market environment - internal, external, or combined.

In economic theory there traditionally exist two predominant trends when explaining the essence of cost, that apply to the concept of cost of factors of production. One, recognizing that labour lies at the basis of cost has been called time-labour. The other, considering that the utility of a commodity is the basis of cost, belongs to the marginal school represented by E. von Böhm-Baverk, C. Menger and F. von Wieser with their theory of marginal utility, and also with E. Chamberlin and A. Pigou, who expounded the theory of supply and demand.

Marginal economic theories direct their main emphasis to the solution to the questions "to produce for whom", and "how to produce", and also to discover optimal equilibrium in the use of factors of production. This concept, 
with which we agree in principle, confirms the appropriateness of its existence in practice, since underestimation of price factors, and of their role and significance in production, inevitably leads to a reduction in labour efficiency in business processes. However, this does not apply to the action of monopolistic prices prevailing in the modern Russian economy, which is characterized by the predominance of monopolistic and oligopolistic markets.

The origin of the cost-of-production theory of value is associated with A. Smith, D. Ricardo, K. Marx, and others The fundamental elements of labour value developed from this theory. Based on the leading role of labour productivity, it is recognized that the only source of cost is the worker's labour, which lies at the basis of wages, interest and rent. It has also been shown conclusively that the abstract cost of any commodity is determined by the total costs of production.

Since then economic thinking has been developed by other theories that are appropriate to the state of material production at different periods of development. So, representatives of the neoclassical school and adherents of the Western economic school such as A. Marshall, J. Keynes, J. Robinson, and others, sought and found points of contact between the theory of production costs, the theory of supply and demand, and the theory of marginal utility (Marshall, 1993; Marshall, 1993).

Marshall included in the theory concepts from other doctrines: from the theory of factors of production - the explanation of the principle of the supply of goods; and from the theory of marginal utility - the explanation of the principle of consumer demand. He considered that total costs are made up by the amount of expended labour input, and also by the amount of capital spent on labour equipment needed, and maintained that only labour that satisfies future, not daily, wants, should be regarded as productive. To this we would add that capital is also a product of labour, therefore the tenets of the labour theory of value as regards labour, which is embodied in the means of production and accounted for in the costs, apply to it.

In particular, Ignatovsky states directly that "labour is the general source of material and spiritual benefit", and "other problems occur on the surface of economic practice that are beyond the limits of production, and that create another appearance of economic life, and of the goals of economic activity, which often puts the role of labour in the shade ... But the essence of the development of production lies in the reduction of labour costs, and in this its economic result is seen" (Ignatovsky, 1995, p. 70). This author devised the following formula: "The concentrated essence of management lies in the combination: costs - productivity - capital input," (Ignatovsky, 1994) costs occupy the first place, including wages and pre-determining prices.

We should look at the idea proposed by Punin, namely: the theory of marginal utility and the labour theory of value do not exclude, but rather complement, each other (Ignatovsky, 1994). As evidence of this it is not the entire concept of both schools in general that is adopted, but only those positions are considered that have been validated by practice. We regard Punin's conclusion that the cost of things, both the finished product and its production costs, include both factors: the costs of labour, and utility, as sufficiently valid and able to simplify the task of optimizing costs separately from the material production. So, based on the binary nature of costs A.N. Polozova and V. V. Grigorieva have devised recommendations for determining and saving costs in dairy production enterprises on the basis of their study of them in food production. (Punin, 1993; Polozova \& Grigorieva, 2002; Polozova \& Grigorieva, 2003).

The position taken by K. Howard, G. Zhuravleva, and N. Eriashvili agrees with Punin's conclusion. They confirm that if cost is labour input, then value reflects a synthesis of costs and the end results of these costs (Polozova \& Grigorieva, 2003).

Therefore, in modern cost theory individual costs of production and supply that fundamentally have a time-labour nature are the basis of the profitability of individual goods manufacturers. According to the theory of labour in its traditional form, cost is the embodied labour of goods producers, and the amount of the cost of the commodity (resource) is determined by the quantity of abstract labour necessary for its production at a particular level of development of social production. Labour then is measured in the working time needed for the manufacture of a particular commodity (resource).

As is well known, Adam Smith introduced the concept of variable labour input as a factor in the formation of cost. David Ricardo, further developing the ideas of Smith, created a model of cost as the sum of labour input, determined according to the principle of added value within the framework of a vertical integrated process of goods production. Cost (S) according to the classical theory of Smith and Ricardo is formally expressed as:

$$
\mathrm{S}=\mathrm{C}+\mathrm{V}+\mathrm{P}
$$

where $\mathrm{C}=$ the cost of capital 
$\mathrm{V}=$ wages

$\mathrm{P}=$ profit

Karl Marx, who introduced the concept of socially necessary costs, occurring due to previous labour input in earlier stages of the production process, and of the input of living labour, further developed the idea of cost, showing that it contains the cost of the means of production that are used and the newly created cost, formed by living labour. This newly created cost includes the cost of the essential surplus product. Thus the formula for cost has become:

$$
\mathrm{S}=\mathrm{C}+\mathrm{V}+\mathrm{m}
$$

Where $\mathrm{C}=$ constant and working capital

$\mathrm{V}=$ variable capital

$\mathrm{m}=$ surplus cost

The goal of the labour theory of value consists particularly in the fact that, in order to justify the position on the basis of any price, including the prices of the factors of production, when interpreting the relationship between the time-labour cost and price, there are time-labour costs, estimated not directly, as in a simple goods production process, but in a converted form - in the prices of a capitalist economy. The divergence of price from cost signifies not a change in the essence of cost, but only a redistribution between goods. So, estimating costs according to the prices of the factors of production, we think that there is a certain level of labour input embodied in them.

The same objective economic laws which are inherent in any individual commodity - the law of value and the law of use-value, are in the nature of the prices of factors of production. Not only the amount of time spent on creating the factors of production changes, but the factors themselves change, that is use-value. So, on the basis of prices, lies the dialectical unity of labour input and the results of labour. These two fundamental factors create the basis of price. But other factors impact on price in the modern market economy and these create divergences from their base: the law of supply and demand, the law of money circulation, including inflation, the presence of monopolies in the market, and so on. The works of Keynes (Howard, Zhuravleva, \& Eriashvili, 1997) and other Western Neo-Keynesian economists (e.g. E. Chamberlin and J. Robinson) state that in a situation where there is imperfect competition, oligopolistic firms are able to manipulate prices, by putting pressure on the market, and on supply and demand. If there are no restraining principles, or where these are weak, then price becomes not only a reflection of labour input, but also of the demand of the seller or buyer. If in this case the amount of production is reduced as a result of price manipulations, then the role of labour and its productivity is also reduced.

The methodology and practice actually acting on the level of total costs as the sum of the cost of the factors of production can be expressed by the following individual positions:

From the position of the interests of the manufacturer alone, who is striving to cover his costs and expenses, and to receive a guaranteed profit without taking into account how useful the manufactured products are to the consumer;

From the position of utility, where the economy of individual production is not taken into account;

From the position of the action of market competition, under the impact of which the price of a production factor reflects the binary nature of the commodity;

From the position of the presence of monopolies in the market, including non-market regulators of production factor prices.

Such practice does not allow for an objective evaluation of the creation of the end product, which is what it costs the vertically integrated manufacturer. We therefore consider it necessary to use a more appropriate instrument in our evaluation of the efficiency of individual costs of production of individual goods, without the disadvantages mentioned above, but adequate for a fundamental cost base.

Bearing in mind that production factors have the nature of a commodity and are acquired on the basis of cost, the amount of costs and expenses deployed on the manufacture of products in conditions of a particular producer (C) may be expressed as the sum of the factors of production:

$$
S=\sum_{i=1}^{n} \sum_{j=1}^{N} W_{i j}+\sum_{i=1}^{n} E_{i}
$$


where $\mathrm{Wij}=$ wages of the $\mathrm{j}$-th worker in the $\mathrm{i}$-th business production process

$\mathrm{N}=$ the number of workers performing the $\mathrm{i}$-th business production process

$\mathrm{n}=$ the number of business processes, beginning with the creation of the objects and means of labour to the end product.

$\mathrm{Ei}$ = the synergistic effect contained in the price of a product of the $\mathrm{i}$-th business production process, validated by A. N. Polozova and R. V. Nuzhdin (Keynes, 1993).

All cost components, set out in formula (3) are determined by the amount of labour in its converted form, which it is possible to buy or obtain in every business process when manufacturing an end product, since "labour determines not only that part of the price which goes to wages, but also the parts that go to rent and profit"

(Polozova \& Nuzhdin, 2012, p. 120), by virtue of the ability of labour to create surplus produce.

So, labour is one of the main factors of production and the vehicle of labour is human labour-power. The main characteristic of labour as an economic category is that it is not separate from the person and his capacity for work, and therefore it has a social aspect. Another characteristic of labour is its commodity-like nature in market economy conditions. In foreign economic theories labour is considered a commodity, whereas among Marxist economists capacity for labour, or labour-power, is a commodity. But in all instances a commodity must have a price, and it is wages that act as a market price in this case (Alekhina, 1993).

Based on the classical cost formula, and deploying logic and grouping, it is possible to express costs not as a price measure, which is not able today to reflect the substance of costs with sufficient objectivity, but to employ methods of measurement that give a more accurate picture of what the creation of the product costs society and the individual manufacturer. Formula (4) sets out the expression of a commodity's cost (S):

$$
C=\sum_{i=1}^{k} S_{i}
$$

where $\mathrm{S}=$ size of the $\mathrm{i}$-th production factor in the costs

$\mathrm{k}=$ the number of production factors in the costs

We wanted to know how objectively labour costs can be evaluated using a wage indicator as a measure. After analysing the interpretation of the economic nature of wages as sources belonging to different economic schools (Amosov, Arkhipov, \& Bolshakov, 2010; Marx \& Engels, 1968; Borisov, 2011) we explained the concept of wages in a market economy by means of their complementarity. This is the price of an employee's labour-power creating the part of the cost of a product that corresponds to his capacity for work and to the correlation of supply and demand of labour-power in the labour market.

Thus, labour has its natural and market price. The natural price of labour is that which is needed for the reproduction of labour-power, to which the employee lays claim, and which tends to increase as society progresses. The market price of labour is that price which actually pays for it due to the natural relationship between supply and demand. We have formulated three variants of the correlation between cost and price of labour-power: 1st: if demand for labour-power is equal to its supply, then wages (the price of labour) are equal to the cost of the labour-power; 2nd: if demand for labour-power exceeds its supply, the price of labour in the form of wages is higher than the cost of labour-power; 3rd: if the supply of labour-power is greater than the demand for it, then the price of labour, that is the wage levels offered, does not cover the cost of labour-power.

Among the subjective reasons for the distortion in the interconnection between remuneration and labour input within the Russian economy today are the following. First, competition in the supply of labour-power as a consequence of cyclical unemployment during the economic crisis. Second, the elimination of the state from wage regulation, as a consequence of which society has passed from an extra-market model of wages at the state level to an extra-market model of wages at enterprise level. Third, the absence of institutions consolidating legal interests in the sphere of the labour of employees as owners of labour-power.

Thus, out of all production relations, wages are considered an element of total costs, on the one hand, and as a portion of the worker's labour put into the created product, on the other. As an element of total costs wages must impact on the economic result of production - the synergistic effect. As a portion of the newly created cost, wages form the mass of important means for its reproduction. In the first and second hypostases wages must be closely linked to labour productivity and the end result of production.

However, at the present time wages as an economic category showing the cost of labour, stimulating its efficiency, and being an important factor within total costs, cease to fulfil their basic functions - the reproduction 
of labour-power, and stimulation of labour. For the reasons already mentioned wages in current economic conditions are not suitable for use as an objective measure of the total costs of goods production using formulae (3) and (4).

\section{Conclusion}

The measure of total costs based on measuring a fixed working time, which usually shows the volume of jobs done, is more expedient than full cost indicators. (Oksanova, 2003, p. 270). The application of such an evaluation of the results of production activity allows them to be presented more accurately, without the distorting influence of monopolistic prices, to show the impact of utilization factors of production resources on the output of goods, and the total income received, and the synergistic effect.

By transforming formulae (3) and (4) the total costs of living labour in every individual business process within the total process may be expressed as:

$$
T=\sum_{i=1}^{n} \sum_{j=1}^{N} t_{i j}
$$

where tij $=$ the labour contribution of the $\mathrm{j}$-th worker in the $\mathrm{i}$-th business process of the total manufacturing process.

The proposed time-labour evaluation of total costs is free from the distorting impact of cost, when prices of production resources diverge from cost, and wages from the cost of labour-power. It reflects an original time-labour substance to the costs. Therefore the amount of costs depends only on how productively and economically, that is, competitively; individual labour is utilized in every business production process in individual business entities.

\section{Acknowledgements}

The authors would like to thank the two anonymous referees and the Editor for their constructive comments and suggestions that improved our paper.

\section{References:}

Alekhina, O. A. (1993). Anthology of economic classics (p. 457). Moscow: Ekonom.

Amosov, A. I., Arkhipov, A. I., \& Bolshakov, A. K. (2010). Economic theory (p. 608). Moscow: TK Velbi; Prospekt.

Bakanov, I. M., \& Sheremet, M. I. (1996). Theory of economic analysis (p. 416). Student's book, 4th edition, revised. Moscow: Finances and statistics.

Borisov, E. F. (2011). Economic theory (2nd ed., revised., p. 544). Moscow: Prospekt.

Grigorieva, V. V., \& Polozova, A. N. (2013). The economic nature of stable competitive production costs. Economics and entrepreneurship, 8(37), 431-435.

Howard, K., Zhuravleva, G., \& Eriashvili, N. (1997). Economic theory. Free market theory (p. 277). Moscow: Banks and stock markets, UNITY.

Ignatovsky, P. (1994a). Labour and the economy. Ekonomist, 10, 69-82.

Ignatovsky, P. (1994b). The logic of the economy: Costs - productivity - capital input. Ekonomist, 10, 69-82.

Ignatovsky, P. (1995). Labour and the economy. Ekonomist, 11, 70-81.

Keynes, J. (1993). Selected works (p. 300). Moscow: Ekonomika.

Marshall, A. (1993a). Principles of economics (Vol. 1, p. 451). Moscow: Progress.

Marshall, A. (1993b). Principles of economics (Vol. 2, p. 310). Moscow: Progress.

Marx, K., \& Engels, F. (1968). Letters about capital. Essays (2nd ed., Vol. 46, p. 117). Moscow: Political Literature Publishing House.

Oksanova, Z. K. (2003). Economic theory (p. 596). Moscow: Dashkov i K.

Polozova, A. N., \& Grigorieva, V. V. (2002). Cost determination in the production of goods in dairy enterprises. The dairy industry, 8, 13-15.

Polozova, A. N., \& Grigorieva, V. V. (2003a). Cost-saving measures through the improvement of labour remuneration. The food industry, 1, 18-19. 
Polozova, A. N., \& Grigorieva, V. V. (2003b). Priorities in labour motivation in reducing production costs. Storage and processing of agricultural raw materials, 2, 67-70.

Polozova, A. N., \& Nuzhdin, R. V. (2012). Methodological approaches to the determination and distribution of the synergistic effect. Economics and entrepreneurship, 1, 244-248.

Punin, E. I. (1993). Marketing, management and pricing within an enterprise (p. 196). Moscow: International relations.

\section{Copyrights}

Copyright for this article is retained by the author(s), with first publication rights granted to the journal.

This is an open-access article distributed under the terms and conditions of the Creative Commons Attribution license (http://creativecommons.org/licenses/by/3.0/). 